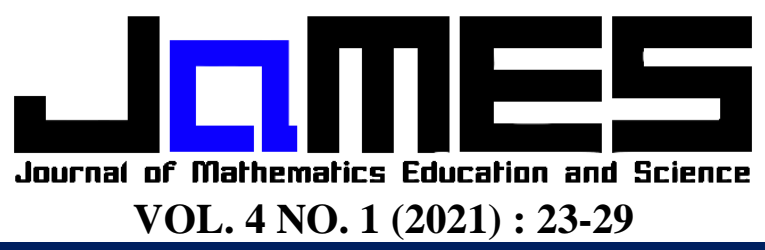

p-ISSN: 2621-1203 | https://doi.org/10.32665/james.v4i1.172

e-ISSN: 2621-1211

\title{
PENINGKATAN KEMAMPUAN KOMUNIKASI MATEMATIS: DAMPAK PENDEKATAN MATEMATIKA REALISTIK INDONESIA (PMRI) BERNUANSA ISLAMI
}

\author{
Renny Yuliyanti ${ }^{1}$, Ruhban Masykur ${ }^{2}$, Indah Resti Ayuni Suri ${ }^{3}$ \\ Universitas Islam Negeri Raden Intan Lampung, renny1675@ gmail.com ${ }^{1}$ \\ Universitas Islam Negeri Raden Intan Lampung, rmasykur@yahoo.co.id ${ }^{2}$ \\ Universitas Islam Negeri Raden Intan Lampung, indahresti@gmail.com ${ }^{3}$ \\ Received : 1 Desember 2020, Revised : 26 April 2021, Accepted : 27 April 2021 \\ (C) Mathematics Education Unugiri 2021
}

\begin{abstract}
The low ability of mathematical communication at SMP Negeri 1 Way Bungur, East Lampung is due to various factors, including the assumption that mathematics is complicated, a lack of curiosity about mathematics, and a lack of variation in learning models, so that students still tend to be passive. The purpose of this study was to determine the mathematical communication skills of students who use the Islamic-nuanced Indonesian Realistic Mathematics Education (PMRI) approach better than ordinary learning. The research method used is a quantitative method using the Quasi-Experimental Design method. The data collection techniques used in the study were: documentation, tests in the form of essay questions to determine the effect of the Islamic-nuanced Indonesian Realistic Mathematics Education (PMRI) approach to improve mathematical communication skills. This study indicates an increase in the mathematical communication skills of students who are given an Islamic approach to Indonesian Realistic Mathematics Education (PMRI) with ordinary learning. Increasing students' mathematical communication skills with the Islamicnuanced Indonesian Realistic Mathematics Education (PMRI) approach is better than regular learning. So it can be concluded that the Islamic-nuanced Indonesian Realistic Mathematics Education (PMRI) approach can improve mathematical communication skills compared to ordinary learning.
\end{abstract}

Keywords : Mathematical Communication Capabilities, PMRI, Islamic Nuances

\begin{abstract}
Abstrak
Berdasarkan latar belakang dan rumusan masalah di atas, maka peneliti memiliki tujuan yaitu untuk mengetahui Pengaruh Pendekatan Pendidikan Matematika Realistik Indonesia (PMRI) bernuansa Islami dalam meningkatkan kemampuan komunikasi matematis yang terdapat pada peserta didik di SMP Negeri 1 Way Bungur. Metode penelitian yang digunakan adalah metode kuantitatif menggunakan metode Quasi Eksperimen Design. Teknik pengumpulan data yang digunakan pada penelitian, yaitu: Dokumentasi, Tes berbentuk soal uraian (essay) untuk mengetahui pengaruh pendekatan Pendidikan Matematika Realistik Indonesia (PMRI) bernuansa Islami untuk meningkatkan kemampuan komunikasi matematis. Hasil penelitian ini bahwa adanya pengaruh peningkatan kemampuan komunikasi matematis peserta didik yang diberi pendekatan Pendidikan Matematika Realistik Indonesia (PMRI) bernuansa Islami dengan pembelajaran biasa. Peningkatan kemampuan komunikasi matematis peserta didik dengan pendekatan Pendidikan Matematika Realistik Indonesia (PMRI) bernuansa Islami lebih baik daripada pembelajaran biasa. Sehingga dapat disimpulkan bahwa pendekatan Pendidikan Matematika Realistik Indonesia (PMRI) bernuansa Islami dapat meningkatkan kemampuan komunikasi matematis dibandingkan dengan pembelajaran biasa.
\end{abstract}

\section{Kata Kunci : Kemampuan Komunikasi Matematis, PMRI, Bernuansa Islami}

\section{Pendahuluan}

Pendidikan adalah sebuah rangkaian proses pemberdayaan manusia Pendidikan diharapkan dapat menghasilkan manusia yang berkualitas dengan mengembangkan potensi secara inovatif dan kreatif sehingga mampu 
bersaing di era global saat ini [1]. Pendidikan tidak dapat dipisahkan dengan mata pelajaran matematika, karena semua tingkatan pasti akan mempelajari matematika. Di dalam mempelajari matematika, peserta didik akan mengetahui manfaat ilmu matematika bagi dirinya sendiri, tidak hanya untuk menghafal rumus matematika saja [2]. Matematika merupakan pembelajaran yang terstruktur antara materi satu dengan yang lainnya. Ketercapaian pendidikan matematika dapat dilihat dari peserta didik yang mampu dalam menyelesaikan tugas-tugas matematika, menerapkan tujuan pendidikan matematika dalam kehidupan sehari-hari dan mengaplikasikannya [3]. National Council of Teacher of Mathematics menyatakan bahwa tujuan dari proses pembelajaran matematika di sekolah yaitu: (1) belajar untuk memecahkan masalah, (2) belajar untuk bernalar, (3) belajar untuk berkomunikasi, (4) belajar untuk menghubungkan gagasan ke dalam matematika (5) belajar untuk melakukan representasi [4]. Sehingga dapat dikatakan bahwa kemampuan komunikasi matematis merupakan salah satu hal penting dalam pembelajaran matematika.

Komunikasi matematis adalah kemampuan peserta didik dalam mengkomunikasikan idenya untuk memecahkan masalah, mempertanggungjawabkan jawabannya, dan aktif dalam berdiskusi [5]. Komunikasi matematis dapat mengorganisasikan dan mengkonsolidasikan pemikiran matematis peserta didik. Kemampuan komunikasi matematis secara umum dapat dilihat dengan dua aspek yaitu komunikasi lisan (talking) dan komunikasi tulisan (writing) [6]. Komunikasi matematis menjadi penting ketika peserta didik melakukan diskusi karena akan berlatih untuk menjelaskan, menggambar, menanyakan dan berkerjasama sehingga mereka dapat memahami konsep matematika dengan membangun mereka sendiri dengan bimbingan guru. Keberhasilan pembelajaran salah satuya dipengaruhi oleh bentuk komunikasi yang digunakan guru pada saat berinteraksi dnengan peserta didik. Komunikasi matematis tidak hanya sekedar menyatakan ide melalui tulisan, melainkan juga kemampuan dalam hal bercakap, menjelaskan, menggambar, mendengarkan, bekerja sama dan menulis.

Masalah yang sering dialami dalam pendidikan pada sekarang adalah kurangnya model pembelajaran sains yang bisa dikombinasikan dengan ilmu agama, karena banyaknya pemisah antara sains dan agama. Dampak dari pemisah kedua ilmu sains dan agama yaitu dalam masyarakat yang beragama islam dan menyebabkan orang yang memiliki kecerdasan sains tetapi miskin dalam nilai spiritual maka sebab itu sangat diperlukan dalam menghasilkan model pembelajaran dan bahan ajar yang terintegrasikan keislaman yang terdapat pada Al-Qur'an dan hadits yang dapat memberikan tanda-tanda keesaan dan kebesaran Allah SWT. . Dalam mengatasi hal ini peneliti merasa dibutuhkannya suatu tindakan oleh para guru dalam proses pembelajaran matematika. Dalam mengatasi hal ini peneliti merasa dibutuhkannya suatu tindakan oleh para guru dalam proses pembelajaran matematika. Salah satunya dengan melalui pendekatan matematika realistik indonesia (PMRI) bernuansa islami.

$$
\text { Pada kegiatan pembelajaran }
$$

menggunakan pendekatan PMRI, guru terlebih dahulu memberikan pengantar materi melalui penyajian bentuk cerita yang berhubungan dengan kehidupan sehari-hari peserta didik. Kemudian peserta didik dibimbing untuk menemukan konsep matematika dari masalah yang diberikan oleh guru, karena peserta didik dituntut untuk lebih aktif dalam kegiatan pembelajaran. Melalui pendekatan PMRI, diharapkan peserta didik dapat mengimplementasikan materi pelajaran dengan kehidupan sehari-hari. Sehingga guru tidak langsung memberikan rumus dan konsep matematika pada saat kegiatan pembelajaran [7].

Penelitian dilaksanakan di SMP Negeri 1 Way Bungur, penulis memilih karena sebelumnya belum pernah diterapkan pembelajaran dengan pendekatan Pendidikan Matematika Realistik Indonesia (PMRI) 
bernuansa islami. Permasalahan yang terdapat di sekolah tersebut yaitu peserta didik kesulitan dalam mempresentasikan penyelesaian soal matematika dan sulit dalam mengkomunikasikan ide-ide matematika dengan simbol, tabel, diagram, atau media yang digunakan untuk memperjelas masalah. Kemampuan memahami dan mengevaluasikan ide-ide matematika dalam menyelesaikan permasalahan sehari-hari secara tertulis masih rendah. Minimnya pengetahuan guru terhadap berbagai macam pendekatan pembelajaran sehingga pada proses pembelajaran masih bersifat teacher center. Akibatnya peserta didik bersifat pasif, cenderung merasa bosan karena terjadi komunikasi satu arah yang memberikan sedikit kesempatan kepada peserta didik untuk berfikir kritis dan berdiskusi dengan peserta didik lain.

Pendekatan pembelajaran yang bernuansa Islami peneliti berharap dapat meningkatkan kemampuan komunikasi matematis peserta didik di SMP Negeri 1 Way Bungur. Rendahnya tingkat komunikasi matematis peserta didik dilapangkan perlu mendapat perhatian yang lebih dari berbagai pihak. Kreatifitas guru dalam menyampaikan pelajaran sangatlah dibutuhkan untuk mendukung peserta didik aktif dalam proses pembelajaran.

Berdasarkan kajian teori yang telah dilakukan, terdapat beberapa penelitian terdahulu yang relevan dengan penelitian yang dilakukan oleh Supriadi pada tahun 2015 yang menggunakan pendekatan pendidikan matematika realistik indonesia (PMRI) dengan geogebra [8]. Penelitian yang dilakukan oleh Kesumawati pada tahun 2012, PMRI untuk meningkatkan kemampuan pemahaman matematis dan penelitian ini untuk meningkatkan kemampuan komunikasi matematis [9]. Hasil dari penelitian yang dilakukan oleh Utami, dkk pada tahun 2018 yaitu modifikasi model pembelajaran Gerlach dan Ely dimodifikasi dengan nilai-nilai keislaman untuk meningkatkan kemampuan dalam representasi matematis [10]. Penelitian yang berkaitan dengan (PMRI) pernah dilakukan oleh Artawan, dkk pada tahun 2014 dengan pendekatan (PMRI) [11].

\section{Metode Penelitian}

Metode penelitian yang digunakan adalah metode kuantitatif menggunakan metode Quasi Eksperimen Design. Adapun desain yang digunakan yaitu pretest-posttest control group design dengan melibatkan dua kelas, yakni kelas yang menggunakan pendekatan pembelajaran Pendidikan Matematika Realistik Indonesia (PMRI) bernuansa Islami dengan kelas yang menggunakan pendekatan pembelajaran konvensional. Populasi pada penelitian ini yaitu seluruh peserta didik kelas VIII di SMPN 1 Way Bungur. Teknik pengambilan sampel yang digunakan pada penelitian yakni Cluster Random Sampling dimana kelas IX B sebagai sampel dalam penelitian. Teknik pengumpulan data yang digunakan pada penelitian, yaitu: Dokumentasi dan Tes berbentuk soal uraian (essay) pada materi persamaan garis lurus untuk mengetahui pengaruh pendekatan Pendidikan Matematika Realistik Indonesia (PMRI) bernuansa Islami untuk meningkatkan kemampuan komunikasi matematis. Adapun indikator yang digunakan untuk mengukur kemampuan komunikasi matematis yakni

a. Menulis matematika (Written Text) merupakan menjelaskan ide dari suatu permasalahan atau gambar dengan menggunakan bahasa sendiri yang jelas dan logis

b. Menggambar matematika (Drawing) merupakan menjelaskan ide dari permasalahan matematika dalam bentuk diagram, grafik dan tabel yang benar dan lengkap.

c. Mengekspresikan matematika (Math. Expressions) merupakan menyatakan masalah atau peristiwa sehari-hari dalam bahasa model matematika mendapatkan hasil yang benar

Pengujian instrumen penelitian digunakan untuk mengetahui validitas, reliabilitas, taraf kesukaran dan daya beda. Setelah dilakukan uji coba isntrumen tes, maka 
peneliti menganalisis hasil uji coba instrumen butir demi butir untuk diteliti kualitasnya. Uji Normalitas menggunakan Uji Liliefors. Uji homogenitas menggunakan uji Bartlett. Uji normalize gain ialah selisih nilai pretest dan posttest. Uji N-gain menunjukkan tingkatan peserta didik untuk memenuhi atau menguasai konsep setelah proses pembelajaran yang dilakukan oleh guru. Uji hipotesis yang digunakan pada penelitian ini yaitu Uji-T.

\section{Pembahasan}

Terdapat dua kelompok dalam penelitian ini yaitu kelas eksperimen dengan perlakuan pendekatan Pendidikan Matematika Realistik Indonesia (PMRI) Bernuansa Islami dan kelas kontrol dengan perlakuan yang berbeda melalui pendekatan konvensional. Setelah penulis melakukan serangkaian penelitian maka didapatkan data yang akan dianalisis yaitu data tes kemampuan komunikasi matematis. Langkah-langkah pendekatan Pendidikan Matematika Realistik Indonesia (PMRI) bernuansa Islami adalah sebagai berikut:

a. Mengkondisikan suasana kelas menjadi kondusif dengan cara menggunakan diskusi dan kelompok, dimana pembagian nama-nama kelompok tersebut menggunakan Asmaul Husna dan menciptakan suasana demokratis dan islami pada saat kegiatan pembelajaran.

b. Memahami dan menyelesaikan masalah kontekstual yang berhubungan dengan kehidupan sehari-hari peserta didik dan mengkaitkan materi dengan ayat Al-Qur'an agar peserta didik memahami masalah yang diberikan. Tema untuk masalah kontekstual dapat menyesuaikan dengan materi yang akan diberikan ke peserta didik, baik lingkungan atau pengalaman peserta didik.

c. Peserta didik diberikan waktu dan kesempatan untuk menyelesaikan masalah kontekstual, kemudian membandingkan dan mendiskusikan jawaban dari soal secara berkelompok dengan cara guru meminta perwakilan dari kelompok untuk mempresentasikan hasil diskusi dan peserta didik lainnya mendengarkan serta menanggapi penjelasan kelompok lain. Peserta didik memberi salam sebelum dan sesudah menyampaikan pendapat.

d. Setelah berdiskusi, peserta didik mendapatkan hasil diskusi kelompok. Selanjutnya guru membimbing peserta didik untuk menarik kesimpulan dari masalah kontekstual selama kegiatan pembelajaran.

e. Peserta didik diberikan penegasan dan pemberian tugas kembali oleh guru.

Untuk mengetahui keadaan awal antara kelompok eksperimen dan kelompok kontrol maka digunakan tes sebelum pembelajaran yaitu Pretest. Deskripsi data hasil Pretest kemampuan komunikasi matematis peserta didik pada materi persamaan garis lurus terangkum pada Tabel 1 .

Tabel 1. Dekripsi Data Skor Pretest Kemampuan Komunikasi Matematis Kelas Eksperimen dan Kelas Kontrol

\begin{tabular}{ccc}
\hline No & Kelas Eksperimen & Kelas Kontrol \\
\cline { 2 - 3 } & Pretest & Pretest \\
\hline 1 & 15 & 15 \\
2 & 35 & 25 \\
3 & 30 & 25 \\
4 & 25 & 30 \\
5 & 45 & 35 \\
6 & 20 & 25 \\
7 & 30 & 20 \\
8 & 35 & 25 \\
9 & 25 & 30 \\
10 & 40 & 35 \\
11 & 20 & 25 \\
12 & 30 & 20 \\
13 & 25 & 30 \\
14 & 35 & 25 \\
15 & 40 & 25 \\
16 & 45 & 40 \\
17 & 20 & 35 \\
18 & 35 & 30 \\
19 & 25 & 30 \\
20 & 30 & 10 \\
21 & 15 & 25 \\
22 & 25 & 20 \\
23 & 20 & 15 \\
24 & 30 & 30 \\
25 & 35 & 35 \\
26 & 40 & 40 \\
27 & 30 & 20 \\
28 & 35 & 20 \\
29 & 35 & 25 \\
30 & 25 & 30 \\
\hline & &
\end{tabular}


Berdasarkan deskripsi data skor Pretest di atas dapat disimpulkan bahwa skor Pretest pada kelas eksperimen mendapatkan nilai tertinggi sebesar 45 dan terendah sebesar 15, sedangkan nilai tertinggi untuk kelas kontrol sebesar 40 dan terendah sebesar 10. Rata-rata kelas (Mean) untuk kelas eksperimen sebesar 29,83 dan kelas kontrol sebesar 26,50. Berdasarkan hasil data Pretest sebelum diberikan perlakuan pada kelas eksperimen maupun kelas kontrol dapat disimpulkan bahwa nilai Pretest masih jauh di bawah kriteria ketuntasan minimum yaitu 73 .

Posttest diterapkan untuk melihat seberapa besar peningkatan kemampuan komunikasi matematis peserta didik kelas eksperimen setelah proses pembelajaran dengan pendekatan Pendidikan Matematika Realistik Indonesia (PMRI) bernuansa Islami maupun kelas kontrol dengan pendekatan konvensional. Posttest dilakukan untuk mengetahui keadaan akhir antara kelompok eksperimen dan kelompok kontrol setelah diberi perlakuan dalam proses pembelajaran. Deskripsi data hasil uji posttest kemampuan komunikasi matematis peserta didik Nampak pada Tabel 2.

Berdasarkan deskripsi skor posttest di atas dapat dilihat bahwa skor tertinggi kelas eksperimen sebesar 95 dan nilai terendah sebesar 65, sedangkan nilai terendah untuk kelas kontrol sebesar 50 dan nilai tertinggi sebesar 90. Rata-rata kelas (Mean) untuk kelas eksperimen sebesar 80.33 dan kelas kontrol sebesar 71,50. Data tersebut dapat disimpulkan bahwa sesudah diberikan posttest diperoleh nilai peserta didik dengan kategori mencapai kriteria ketuntasan minimum.

Setelah dilaksanakan proses pembelajaran pada kelas eksperimen dan kelas kontrol kemudian dilakukan posttest. Data nilai pretest dan posttest yang telah dilakukan digunakan untuk mengetahui seberapa besar peningkatan kemampuan komunikasi matematis peserta didik dengan perhitungan rumus normalitas gain (n-gain). Data peningkatan kemampuan komunikasi matematis peserta didik pada materi persamaan garis lurus terangkum dalam Tabel 3.
Berdasarkan tabel di atas dapat diketahui bahwa Nilai n-gain pada kelas eksperimen dengan klasifikasi sedang yaitu 0.56 sampai tinggi yaitu 0.92 dengan rata-rata kelas (mean)

Tabel 2. Dekripsi Data Postest Skor Kemampuan Komunikasi Matematis Kelas Eksperimen dan Kelas Kontrol

\begin{tabular}{|c|c|c|}
\hline \multirow[t]{2}{*}{ No } & Kelas Eksperimen & Kelas Kontrol \\
\hline & Postest & Postest \\
\hline 1 & 15 & 50 \\
\hline 2 & 25 & 65 \\
\hline 3 & 25 & 70 \\
\hline 4 & 30 & 80 \\
\hline 5 & 35 & 85 \\
\hline 6 & 25 & 75 \\
\hline 7 & 20 & 60 \\
\hline 8 & 25 & 70 \\
\hline 9 & 30 & 75 \\
\hline 10 & 35 & 80 \\
\hline 11 & 25 & 70 \\
\hline 12 & 20 & 65 \\
\hline 13 & 30 & 80 \\
\hline 14 & 25 & 55 \\
\hline 15 & 25 & 65 \\
\hline 16 & 40 & 85 \\
\hline 17 & 35 & 75 \\
\hline 18 & 30 & 70 \\
\hline 19 & 30 & 75 \\
\hline 20 & 10 & 65 \\
\hline 21 & 25 & 80 \\
\hline 22 & 20 & 70 \\
\hline 23 & 15 & 65 \\
\hline 24 & 30 & 75 \\
\hline 25 & 35 & 85 \\
\hline 26 & 40 & 90 \\
\hline 27 & 20 & 60 \\
\hline 28 & 20 & 75 \\
\hline 29 & 25 & 70 \\
\hline 30 & 30 & 70 \\
\hline
\end{tabular}

Tabel 3. Deskripsi Hasil N-Gain Kemampuan Komunikasi Matematis

\begin{tabular}{cccccc}
\multicolumn{6}{c}{ Komunikasi Matematis } \\
\hline \multicolumn{7}{c}{ Descriptive Statistics } \\
\hline $\begin{array}{c}\text { N-Gain } \\
\text { Eksperimen } \\
\text { N-Gain } \\
\text { Kontrol } \\
\begin{array}{c}\text { Valid N } \\
\text { (listwise) }\end{array}\end{array}$ & 30 & 0,56 & 0,92 & 0,7261 & 0,10434 \\
\hline
\end{tabular}

sebesar 0.7261. Sedangkan kelas kontrol dengan klasifikasi sedang yaitu 0.40 sampai tinggi yaitu 0.83 dengan rata-rata kelas (mean) 
sebesar 0.6183 Kesimpulan dari data tersebut bahwa, sesudah diberikan pretest dan posttest pada masing-masing peserta didik mengalami rata-rata peningkatan kemampuan komunikasi matematis sebesar 0,7261 pada kelas eksperimen Sedangkan pada kelas kontrol yaitu 0.6183 .

Hasil uji normalitas menunjukkan bahwa sampel berasal dari populasi yang berdistribusi normal, sehingga dapat diuji homogenitasnya. Berdasarkan analisis homogenitas diketahui bahwa nilai hasil pembelajaran matematika peserta didik pada dua sampel memiliki varians yang sama. Setelah diketahui bahwa data sampel berasal dari populasi yang normal dan homogen, selanjutnya penulis melakukan perhitungan uji-t independen untuk menguji hipotesis.

Hasil perhitungan uji-t independen pada analisis pretest, menunjukkan bahwa sehingga $\mathrm{H}_{0}$ diterima. Sehingga, dapat disimpulkan bahwa rata-rata peningkatan kemampuan komunikasi matematis peserta didik yang akan diberi pendekatan Pendidikan Matematika Realistik Indonesia (PMRI) bernuansa Islami sama dengan rata-rata peningkatan kemampuan komunikasi matematis peserta didik yang akan diberi pendekatan konvensional. Hasil analisis uji-t independen data posttest menunjukkan bahwa $\mathrm{H}_{0}$ ditolak. Sehingga, peningkatan kemampuan komunikasi matematis peserta didik yang diberi pendekatan Pendidikan Matematika Realistik Indonesia (PMRI) bernuansa Islami meningkat.

Data peningkatan kemampuan komunikasi matematis peserta didik diperoleh dari data n-gain yang menunjukkan bahwa ratarata n-gain pada kelas eksperimen sebesar 0,7261 sedangkan pada kelas kontrol yaitu 0,6183 . Berdasarkan data rata-rata n-gain tersebut, dapat dilihat bahwa rata-rata n-gain kelas eksperimen lebih tinggi dari kelas kontrol. Berdasarkan penjelasan tersebut maka dapat penulis simpulkan, bahwa pengaruh pendekatan Pendidikan Matematika Realistik Indonesia (PMRI) bernuansa Islami lebih efektif untuk meningkatkan kemampuan komunikasi matematis peserta didik.
Hasil penelitian yang dilakukan oleh Nila Kesumawati diperoleh bahwa peningkatan kemampuan pemahaman matematis peserta didik yang mendapat pembelajaran dengan pendekatan PMRI lebih baik daripada peserta didik yang mendapat pembelajaran konvensional. Hasil dari penelitian yang dilakukan oleh Irda Yustika, R. Masykur, Suherman, dengan judul penelitiannya yaitu modifikasi model pembelajaran Gerlach dan Ely dimodifikasi dengan nilai-nilai keislaman untuk meningkatkan kemampuan dalam representasi matematis yaitu peserta didik yang terintegrasi nilai-nilai keislaman dalam pembelajaran matematika mengalami peningkatan dan lebih baik dibandingkan dengan menggunakan pembelajaran konvensional. Kesimpulan dari hasil penelitiannya yaitu peserta didik yang diberikan pembelajaran dengan menggunakan nilai-nilai keislaman terbukti dapat meningkatkan peserta didik dalam pembelajaran.

\section{Penutup}

Berdasarkan penelitian, analisis, dan pengolahan data terlihat bahwa adanya pengaruh peningkatan kemampuan komunikasi matematis peserta didik yang diberi pendekatan Pendidikan Matematika Realistik Indonesia (PMRI) bernuansa Islami dengan pembelajaran biasa. Peningkatan kemampuan komunikasi matematis peserta didik dengan pendekatan Pendidikan Matematika Realistik Indonesia (PMRI) bernuansa Islami lebih baik daripada pembelajaran biasa. Dapat disimpulkan bahwa pendekatan Pendidikan Matematika Realistik Indonesia (PMRI) bernuansa Islami dapat meningkatkan kemampuan komunikasi matematis dibandingkan dengan pembelajaran biasa.

Saran yang dapat disampaikan berdasarkan penelitian yang telah dilakukan adalah bagi peserta didik yaitu dapat meningkatkan kemampuan dalam menyampaikan ide pendapat dengan fasilitas yang ada untuk belajar mengkomunikasikan suatu permasalahan di kelas atau dengan teman sejawat agar terciptanya pembelajaran aktif. 


\section{Referensi}

[1] Dayu Citra Wahyuni, Iip Sugiharta. Blended Learning dan E-Learning Berbasis Edmodo Dalam Peningkatan Motivasi Belajar Matematika. AlKhawarizmi: Jurnal Pendidikan Matematika Dan Ilmu Pengetahuan Alam, 7(1). (2019).

[2] Miftahul Ulva dan Indah Resti Ayuni Suri. Pengaruh Model Pembelajaran Auditory Intellectualy Repetition Terhadap Kemampuan Komunikasi Matematis Peserta Didik. UNION: Jurnal Pendidikan Matematika, 7(1). (2019).

[3] Muhammad Yasin. Analisis Kesulitan Belajar: Dampak Latar Belakang Kejuruan ditinjau dari Proses Pembelajaran Matematika Perguruan Tinggi. Desimal: Jurnal Matematika, 2(1). (2019).

[4] Ratna Ambarwati, Dwijanto, dan Putriaji Hendikawati. Keefektifan Model ProjectBased Learning Berbasis GQM Terhadap Kemampuan Komunikasi Matematis Dan Percaya Diri Siswa Kelas VII. Unnes Journal of Methematics Edcation, 4(2). (2015).

[5] Fredi Ganda Putra. Pengaruh Model Pembelajaran Reflektif dengan Pendekatan Matematika Realistik Bernuansa KeIslaman Terhadap Kemampuan Komunikasi Matematis Peserta Didik. Al-Jabar: Jurnal Pendidikan Matematika, 7(2). (2016).

[6] Lekok Melya dan Nanang Supriadi. Analisis Kemampuan Komunikasi Matematis Ditinjau dari Tipe Kepribadian Guardian dan Idealist. Desimal: Jurnal Matematika, 1(3). (2018).
[7] Yosmarniati, Edwin Musdi, Yusmet Rizal. Upaya Meningkatkan Kemampuan Komunikasi Matematika Siswa Melalui Pendekatan Pendidikan Matematika Realistik. Jurnal Pendidikan Matematika, Part 3, 1(1), (2012).

[8] Supriadi, N. Pembelajaran geometri berbasis geogebra sebagai upaya meningkatkan kemampuan komunikasi matematis siswa madrasah tsanawiyah (MTs). Al-Jabar: Jurnal Pendidikan Matematika, 6(2), (2015), 99-110.

[9] Kesumawati, N. Meningkatkan kemampuan pemahaman matematis siswa SMP melalui pendekatan Pendidikan Matematika Realistik Indonesia (PMRI). Jurnal Pendidikan Matematika, 6(2), (2012). 30-44.

[10] Utami, T. N., Jatmiko, A., \& Suherman, S. Pengembangan Modul Matematika dengan Pendekatan Science, Technology, Engineering, And Mathematics (STEM) pada Materi Segiempat. Desimal: Jurnal Matematika, 1(2), (2018), 165-172.

[11] Artawan, K. A., Japa, I. G. N., \& Suarjana, I. M. Penerapan pendekatan pendidikan matematika realistik indonesia untuk meningkatkan aktivitas dan hasil belajar matematika siswa kelas v sd negeri 4 suwug kecamatan sawan kabupaten buleleng tahun pelajaran 2013/2014. MIMBAR PGSD Undiksha, 2(1). (2014). 
http://journal.unugiri.ac.id/index.php/JaMES 